\title{
Has the White-necked Picathartes Picathartes gymnocephala still a chance in Lamto, Ivory Coast?
}

\author{
VOLKER SALEWSKI, FRANK GÖKEN, JUDITH KORB and SILKE \\ SCHMIDT
}

\begin{abstract}
Summary
A rocky area in Lamto, Ivory Coast, which is partly surrounded by plantations, was searched for nests of the White-necked Picathartes Picathartes gymnocephala. A total of 34 nests was found of which 10 were only remnants, 12 old and 12 rather new. One nest contained two chicks. It is suggested that ecotourism might be a suitable means to help to protect the species, but care has to be taken to avoid any further disturbance.
\end{abstract}

The genus Picathartes, with uncertain systematic status (Thompson and Fotso 1995), is represented by two species in Africa. According to DNA and anatomical analysis Picathartes shows affinities to the Corvidae but with separate family status (Sibley and Ahlquist 1990). They may, however, represent an order of their own (Thompson and Fotso 1995). The White-necked Picathartes Picathartes gymnocephalus Temminck lives in West Africa between Guinea and Ghana (Dowsett and Forbes-Watson 1993, Thompson and Fotso 1995) where it inhabits primary or secondary forests in the Upper Guinea Forest Zone. The species is most likely not present in Togo. The locality where a nest was reported in 1894 (Collar and Stuart 1985) lies in Ghana (Cheke and Walsh 1996). In the forest zone east of the Benin Gap from Nigeria to Gabon the White-necked Picathartes is replaced by the Grey-necked Picathartes P. oreas Reichenow (Thompson and Fotso 1995). Both species are similar in appearance and behaviour. They inhabit dense undergrowth where they are mainly ground dwelling. The species breed in small colonies in caves and on rocks where they build their mudnests often under overhanging ledges under rainforest canopy; breeding is associated with the rainy season (Collar and Stuart 1985, Thompson and Fotso 1995). Their food consists largely of insects, small molluscs and vertebrates which they take mainly from the forest floor (Thompson and Fotso 1995), and they are reported to join mixed-species flocks which follow army ant Dorylus sp. columns (Walker 1939, Demey and Fishpool 1991, K. Bergmann pers. com.).

In the Ivory Coast, the White-necked Picathartes is one of six bird species listed as vulnerable (Collar and Stuart 1985). In March 1968, Brunel and Thiollay (1969) discovered a small colony with six nests at Mount Nimba, of which two contained two eggs each. Since then there have been no reports from this colony (J.-M. Thiollay pers. comm.). Gartshore (1989) found an active breeding colony 
on the south-eastern slope of Mount Niénokoué in Tai National Park in March 1989. The site was checked for nests by K. Bergmann (pers. comm.) in 1994 and 1996 and the colony is still active (G. Radl pers. comm.). Recently, the Whitenecked Picathartes was found at Mount Peko (Yaokokoré 1997). An additional breeding population was discovered near the research station of Lamto $\left(6^{\circ} 13^{\prime} \mathrm{N}\right.$, $5^{\circ} \mathrm{O}^{\prime} \mathrm{W}$ ) in May 1990 by Demey and Fishpool (1991).

The habitat around Lamto is mainly savanna dominated by palms Borassus aethiopium. It is the southernmost tip of the savanna belt in Ivory Coast and belongs to the humid south Guinea savanna, which typically fringes the northern limits of the forest zone and of which it is one of the last remnants (Thiollay 1998). Along the River Bandama, riverine forest is found from which a network of galleries penetrates into the savanna habitat and there are also some small isolated forests. The savanna is burned annually by controlled fires according to a management plan. Since 1963, an area around the research station has been protected from the fires and is turning into forest, and from 1963 to 1988 the forest cover increased from $15.6 \%$ to $17.9 \%$ (Thiollay 1998). In the early 1980 , the introduced shrub Chromolaena odorata began to invade the reserve and is now present in almost all the forest areas. The research station in Lamto was founded in 1962 and it is surrounded by a reserve which covers 2,700 ha. The reserve has no official protective status, but it has recently been nominated as a Man and Biosphere Reserve of UNESCO (Thiollay 1998, R. Vuattoux pers. comm.).

The White-necked Picathartes colony discovered near Lamto consisted of at least 15 nests, of which six were under active construction (Demey and Fishpool 1991). There were observations of single birds "apparently a long way from suitable breeding sites" (Collar and Stuart 1985) in 1981 and 1982 (Prendergast 1983) and 1987-1988 (Balchin 1988). The habitat in Lamto seemed to be unsuitable for a breeding colony of picathartes because there were no extended rocky areas in the forest known in the vicinity of the research station and it was speculated whether the species is a seasonal migrant to the region. Some years after the discovery of the colony, Borrow (1994) reported that it no longer existed because the area had been cleared and turned into a banana plantation. In December 1993-January 1994 only "one and a half disused nests" were found and one bird was seen. Nevertheless, in 1995 four new nests were reported from Lamto without any detailed description of the site (Anonymus 1995). These are apparently the last available records of the species in Lamto, although local people from the small camp for employees near the research station claimed that the species can be seen feeding at the camp's refuse tip. In 1998, L. Fishpool (pers. comm.) questioned whether the colony is still there because local farmers had already started to establish banana plantations at the site in 1990.

In November 1997, two of us (V.S., J.K.) stayed in Lamto for a brief visit. A group of large rocks at the fringe of the savanna in open habitat was visited but not inspected carefully, because it was thought that the area was not suitable for the species owing to the banana and yam plantations situated around and partially between the rocks, and there was hardly any tree cover. Later, L. Fishpool (pers. comm.) described where he discovered the nests of picathartes and the description corresponded with the rocks which we visited. On 7 November 1998, the rocks were inspected again by V.S., F.G., J.K. and 24 nests were found. They were arranged in four groups. At one place there were only the remains of one 
very old nest and a second group consisted of the remains of one nest and two complete nests. These nests were built under overhanging rocks of moderate height $(5-8 \mathrm{~m})$ and located about $2-3 \mathrm{~m}$ above the ground. Five more nests were built in a cave-like structure between several rocks at a height of about 3-4 m. One of these nests was old but the other four looked quite new with no sign of decay and a lot of plant material within the mud structure of the nests. The biggest group consisted of 15 nests. They were built under an overhanging rock with a height of about $10-12 \mathrm{~m}$. Four of these nests looked fresh and three still contained nesting material (dry grass). Seven of the nests showed signs of decay and of four nests only remnants were visible. From this location we saw other groups of rocks in the Bandama valley, but it was impossible to reach them at that time, because of the high water level.

Between October and December, we stayed in Lamto five times for 3-5 days each visit. During that time we inspected several groups of rocks in dense gallery forest near the station without finding any additional nests and we also never observed any picathartes.

From the end of January to the end of April, we (V.S., S.S.) stayed regularly in Lamto again. We suspected that the species might still breed there, because of the shape of some of the discovered nests and, therefore, we checked the nests every two weeks for signs of activity. We found no evidence of the presence of picathartes at the nests during the whole period but did find some grey feathers beneath one of the nests in the cave on 15 March. The nests were checked the last time on 24 April. On 31 January we managed to visit some of the other rocks in the Bandama valley but without finding any signs of the presence of picathartes. The rocks there seemed to be unsuitable habitat because the surroundings were very open.

On 26 April, another group of rocks was inspected at the fringe of the gallery forest and six nests were found. These were arranged in three groups of two nests each. There were the remains of one nest and one old nest, one old nest and one fresh nest still containing nesting material and the remains of one nest together with a fresh nest still containing nesting material. It seemed that the last of these was built on the remains of an older nest. All nests were between 1 and $2 \mathrm{~m}$ above the ground. On 27 April, a gulley-like structure, which was lined by big boulders, was discovered in the riverine forest in the vicinity of the described rocks. There, two single nests were found. One was very old, whereas the second one was rather fresh. Additionally, two more nests were found. One of them was very old but at some metres distance the second nest was fresh. A closer inspection revealed that it contained two picathartes chicks whose remiges where just pins.

There are no other recent reports of observations of White-necked Picathartes from Lamto but the active nest and others which looked rather new clearly show that the species is still living and breeding there. Nothing can be said about the numbers of picathartes occurring in Lamto but they are definitely not very common as few fresh nests were found. However, due to its special habitat requirements the species is always very local (Collar and Stuart 1985). The population is probably threatened: the biggest site, which seems to be rather untypical for the species because it is in relatively open habitat, is often visited by local farmers whose fields are spread right beneath the nesting rocks, an activity which 
might disturb breeding birds and it is possible that this site has been abandoned already. When established, the place was probably more densely vegetated; when the colony was discovered people had just started to clear the area (L. Fishpool pers. comm.), although according to local people the location has been used for agriculture for a long time (R. Vuattoux pers. com.). Now there are plantations between the rocks and in April 1999 even more vegetation had been cut down for new fields. Trees are only found on the rocks themselves, or where they lie close together. In contrast, the newly discovered nest localities reported here lie well inside the forest and it seems unlikely that there will be any disturbance by farmers in the near future. Nevertheless these sites might be suboptimal as indicated by the small groups of nests in scattered localities and the discovery of only one active nest of a species which usually breeds in colonies (Thompson and Fotso 1995).

The question remains as to when the colony was established at the present site. The research station was founded in the early 1960s and was the base for intensive ornithological work, especially by Thiollay (1970a, b, 1971, 1985) at the end of the 196os and the beginning of the 1970s. Therefore, it seems unlikely that the species was overlooked for about 20 years until the beginning of the 1980 . It is possible that the birds invaded the area only recently after habitat improvement - the extension of the forest after fires in the area round the station had been discontinued. Most of the sightings of birds are reported from the vicinity of the station (Prendergast 1983, Demey and Fishpool 1991) where they do not breed. The lack of suitable rocks in their preferred habitat might have forced the birds to breed in a relatively open place, which they leave after the breeding season to move into denser forest. Desertion of breeding colonies during the non-breeding season is also reported by Thompson and Fotso (1995), who also speculate that individuals of the species may range over a large area. Another explanation for the establishment of the population might be the construction of the dam on the River Bandama at Taabo some kilometres north of Lamto in 1977 (R. Vuattoux pers. comm.). There were several big rocks in the area which is now flooded which might have been the site of an undiscovered picathartes colony subsequently driven to Lamto by the rising water. This would explain the first observations of the species just a few years after the construction of the dam.

The White-necked Picathartes is listed as vulnerable in every country where it is recorded (Collar and Stuart 1985) and Lamto is one of only two definite breeding sites in Ivory Coast, which gives it a special importance. The main threat for the species, as for all primary forest species, is habitat destruction (Collar and Stuart 1985). To what extent local people hunt the species is not known. According to information from local people (R. Vuattoux pers. comm.), the species is eaten but rarely, probably because it is rare. However, the fact that it has a name in Baoule (the local language) - Bro Ako (bush chicken) - shows that the bird plays or played a role in the life of local people. Thompson and Fotso (1995) report that the birds are protected by locals in some areas for religious reasons. In contrast Brunel and Thiollay (1969) state that the birds are caught in special traps at the Mount Nimba colony.

Action to manage the breeding site in Lamto in order to protect it is complicated by the fact that the rocks lie just outside the boundary of the reserve. Never- 
theless, the species breeds there today although large parts of the suitable area are cleared and visited by people regularly. Collar and Stuart (1985) summarize reports that demonstrate that White-necked Picathartes can tolerate some disturbance and forest clearing around its colonies, which gives hope that the colony near Lamto can persist in the future if the disturbance remains at the present level. To achieve this aim it is necessary to convince local people of the value of the birds. This might be possible if they could gain advantages through ecotourism, for example birders who want to watch this rare and attractive species. Nowhere in the Ivory Coast is it easier to reach the nests of this species. In Tai National Park, for example, it is only possible with a guided tour, which takes two days (G. Radl pers. comm.). With a little care it should be possible to watch the nests and birds at Lamto in the breeding season without any impact. These activities should help to protect the species and might additionally serve as a stimulus to better protect this important last remnant of this type of Borassussavanna. However, visits by birders must be restricted to the farmed area, because it is disturbed already. We considered whether we should publish our observations because it could lead to a rush of people to the nesting area, with negative effects. However, we think that the benefits of this publication may be greater than its potential harm. Nevertheless we appeal to every person visiting the area to keep the impact on picathartes as low as possible and avoid any disturbance at the nests.

\section{Acknowledgements}

We wish to thank F. Bairlein who made our trip to Ivory Coast possible. The president of the University of Abobo, Abidjan and R. Vuattoux, Director of the Ecological Station gave us permission to stay and work in Lamto. Thanks are also due to the employees in Lamto, especially Lazar who made our stay a pleasure there. Germain always told us that "the bird with no feathers on the head" is still there, so we never gave up looking for it, and were successful in the end. R. Vuattoux, L.D.C. Fishpool, J.-M. Thiollay, K. Bergmann and G. Radl provided us with additional information and R. Paul helped us to inspect the rocks in the Bandama valley. G. Manners kindly edited the manuscript.

\section{References}

Anonymus (1995) Recent reports, Ivory Coast. Bull. African Bird Club 2: 124.

Balchin, C. S. (1988) Recent observations of birds from the Ivory Coast. Malimbus 10: 201206.

Borrow, N. (1994) Yellow-headed Picathartes in Côte d'Ivoire. Bull. African Bird Club 1: 8.

Brunel, J. and Thiollay, J.-M. (1969) Liste préliminaire des oiseaux de Côte d'Ivoire. Alauda 37: 230-254, 315-337.

Cheke, R. A. and Walsh, J. F. (1996) The birds of Togo. Tring, U.K.: British Ornithologists' Union (Checklist 14).

Collar, N. J. and Stuart, S. N. (1985) Threatened birds of Africa and related islands. Cambridge, U.K.: International Council for Bird Preservation.

Demey, R. and Fishpool, L. D. C. (1991) Additions and annotations to the avifauna of Côte d'Ivoire. Malimbus 12: 61-86. 
Dowsett, R.J. and Forbes-Wattson, A.D. (1993) Checklist of the birds of the Afrotropical and Malagasy regions.1. Species limits and distribution. Liège: Tauraco Press.

Gartshore, M. E. (1989) An avifaunal survey of Tai National Park, Ivory Coast. Cambridge, U.K.: International Council for Bird Preservation (Study Report 39).

Prendergast, H. D. V. (1983) New records for the Lamto region, Ivory Coast. Malimbus 5: 56.

Sibley, C. G. and Ahlquist, J. E. (1990) Phylogeny and the classification of birds: a study in molecular evolution. New Haven: Yale University Press.

Thiollay, J.-M. (1970a) Le peuplement avien d'un savane préforestière (Lamto, Côte d'Ivoire). Abidjan, Ivory Coast: Dissertation, Université Abidjan.

Thiollay, J.-M. (1970b) Recherches ecologiques dans la savanne de Lamto (Côte d'Ivoire): le peuplement avien. Essai d'etude quantitative. Terre Vie 24: 108-144.

Thiollay, J.-M. (1971) L'avifaune de la région de Lamto (Moyenne Côte d'Ivoire). Ann. Univ. d'Abidjan 4: 5-132.

Thiollay, J.-M. (1985) The birds of Ivory Coast: status and distribution. Malimbus 7: 1-59.

Thiollay, J.-M. (1998) Long-term dynamics of a tropical savannah bird community. Biodivers. Conserv. 7: 1291-1312.

Thompson, H. S. and Fotso, R. (1995) Rockfowl the genus Picathartes. Bull. African Bird Club 2: $25-28$.

Walker, G. R. (1939) Notes on the Birds of Sierra Leone. Ibis 14: 401-450.

Yaokokoré, H. B. (1997) Inventaire preliminaire de l'avifaune des Parcs Nationaux des Iles Ehotile, du Mont Peko et du Mont Nimba, Côte d'Ivoire. Abidjan, Ivory Coast: World Wide Fund for Nature.

VOLKER SALEWSKI, FRANK GÖKEN and SILKE SCHMIDT

Institut für Vogelforschung, "Vogelwarte Helgoland", An der Vogelwarte 21, D-26386 Wilhelmshaven, Germany. E-mail: v.salewski@ifv-terramare.fh-wilhelmshaven.de

JUDITH KORB

CSIRO, Tropical Ecosystems Research Center, GPO Box 1700, Canberra, ACT 2601, Australia 